Edu Sciences J. Vol. 1. No. 3. November 2020, 208-220

\title{
THE INFLUENCE OF TRAINING METHODS AND CONCENTRATION ON THE ABILITY TO ROW DISTANCE OF 1000 METERS
}

\author{
Mariana Ditboya Hukubun \\ Faculty of Teacher Training and Education, Pattimura University \\ email: maarianah@gmail.com
}

\begin{abstract}
This study were aimed to analyze: (1) the difference influence of interval and fartlek training method toward the result ability of Kayak paddle at the distance of 1000 meter, (2) interaction between training and concentration method toward the ability of paddle at the distance of 1000 meter, and (3) difference influence of high concentration trained by interval and fartlek training method toward the result ability of kayak paddle at the distance of 1000 meter, (4) difference influence of low concentration trained by interval and fartlek training method toward the result ability of kayak paddle at the distance of 1000 meter. This experiment research used $2 \times 2$ treatment design. The subjects in this study were Kayak paddle athletes of Maluku Province which concsist of 42 people. The techniques of data analysis used was ANAVA. Based on the hypothesis test, the results of this study are: (1) overall there are significant differences between the interval training method and the fartlek training method on the results of the ability to row 1000 meters in rowing athletes like Maluku. , (2) there is an interaction between the training methods used with concentration on the results of the ability to row 1000 meters in rowing athletes like Maluku. Conclusions: (1) interval training method is better than fartlek training method on the ability to row 1000 meters distance, (2) athletes with high concentration and trained with interval and fartlek training methods are better compared with low concentration athletes who are trained with interval training methods and fartlek.
\end{abstract}

Keywords: Concentration, Exercise method, Rowing Ability.

\section{Introduction}

Swimming is a sport that is widely practiced from children to the elderly. This sport is very useful for educational tools, as a healthy recreation, instill courage, confidence, as a therapy that is widely recommended by doctors. Swimming is one of the activities that have been carried out since ancient times, at that time swimming as an activity to protect themselves in facing natural challenges such as flooding (Kasiyo, 1980).

With the exercise in water, in addition to the earth's gravity factor is also influenced by the compressive power of the water up. Under normal circumstances (on land) the human body can move freely under the influence of gravity, whereas in water we must learn to adjust motion with water. This gives rise to movements that look strange, then create movements that are considered the most beneficial. The movement then became styles in swimming (Roeswan and Soekarno, 1979).

Humans are always influenced by Earth's gravity. In addition to the gravity factor of the human earth is also influenced by the compressive power of water upwards, under normal circumstances (on land) the human body can move freely under the influence of gravity, whereas in water we must learn to adjust motion with water.

Breaststroke swimming is often also referred to as the frog style which is a swimming style that coordinates the movements of the arms and legs or legs similar to the movements of a swimming frog. The prominent resemblance lies in the movement of his legs. Leg and leg movements are important in breaststroke swimming because these two series of 
movements are the main source of strength or a swimmer's impetus in increasing his swimming speed. Breaststroke swimming for leg kicks may be important or even more important than arm movements (Astrand \& Rodahl, 1977).

Thus swimming the more dominant breaststroke is in the arm movements and leg movements, the physical conditions related to the movements of the arms and legs need to be considered is the length of the arms and legs. The strength in the arms and legs is the ability of a group of muscles to be mobilized in the quickest possible time, hence its relationship with the ability to swim breaststroke, which affects the distance of the jump at the start and the amount of thrust when doing the kicking technique.

The success of swimming athlete's achievement is also determined by the mastery of the biomechanics principle of the coach. Some biomechanics principles in swimming are according to Hay, (1985). 1) Plotation (floating) The body's ability to float is very important in carrying out activities in the branch of water sports. In the sport of swimming, someone who has the ability to float can affect the success of learning to swim at the beginner level as well as the success of achieving achievement at the level of a championship. 2) Buoyant Force (buoyancy) is the force acting on a person's body which is equal to zero. So that an object will float only if the body weight <maximum buoyancy. Factors that affect the ability of buoyancy include: a. The volume of air in the lungs, b. Age. c. Fat in the body. d. Bone density. 3) Regular Use of Encouragement. This principle causes the crawl style to be faster than the butterfly or breaststroke. 4) Theory of Multiples Law. If a swimmer makes an arm or leg movement twice the previous speed, then raises the impulse to push forward exactly four times. 5) Surface Drag (surface resistance) The principle of surface resistance is related to friction between the surface of the skin of the body and water. So swimmers try to wear swimwear material that does not cause greater resistance. 7) Wave Drag (wave resistance) Swimmer's breaststroke during the breath taking phase will occur due to water waves from the front of the swimmer. 8) Turbul ence (round). The occurrence of water rotation caused by water that is not able to fill parts of the plane that is not horizontal, so the body must draw a number of water molecules. Law of Action-Reaction. Every movement or action of the arm or leg in the swimmer will result in an adverse reaction.

The relationship of arm length with breaststroke swimming is the amount of traction when making a movement. Aip Sarifudin (1996), arm length is the distance from the upper arm bone (humerus) to the cubit bone (ulna). Meanwhile, according to Sadoso Somarjono (1996), that a person's height is closely related to muscle length. Basically the longer the muscle, the greater the potential strength of the muscle, and the shorter the muscle the smaller the potential strength of the muscle. Someone if the biceps are long, then at :

Table 1. Sleeve length index

\begin{tabular}{|c|c|}
\hline Short & Until 18,9 \\
\hline Medium & $19,0-19,9$ \\
\hline Long & 20,0 \\
\hline
\end{tabular}

(Source: Indriati, 2009)

Thus it can be concluded that the length of the arm is the segment of the arm from the shoulder to the fingers measured from the acromion to the tip of the middle finger measured in an anatomical position. The explanation above has the thought that a person's arm size adjusts to height. The higher a person's body, then the size of the arm will increase too.

Received September $15^{\text {th }} 2020$, Revision October $8^{\text {th }} 2020$, Accepted for publication October $19^{\text {th }} 2020$. 
The relationship between limb length and breaststroke swimming is the magnitude of the push. Relating to Newton's Law 3; that is, where the longer the leg, the action that is given to push the water back will get bigger and the reaction given by the water will also be equal. The relationship between breaststroke swimming ability is affecting the distance of the jump at the start and the amount of thrust when doing the kicking technique.

By stating that students have short, medium, and long limbs. According to Indriati (2009), there is a need for arm-length anthropomertic indices as follows:

\section{Tabel 2. Leg length index}

\begin{tabular}{|l|c|}
\hline Short & Until 18,9 \\
\hline Medium & $19,0-19,9$ \\
\hline Long & 20,0 \\
\hline
\end{tabular}

(Source: Indriati, 2009)

The ability of students to take breaststroke swimming as far as 50 meters is strongly influenced by several factors, including leg length and arm length. While the technical factors, concerning how the breaststroke swimming technique is practiced by students as follows; arm movements, leg movements, breathing and coordinate all movements.

\section{Research Method}

This study is a correlation study with two variables, the independent is arm length, leg length and one dependent variable is the ability to swim breaststroke 50 meters.

The method used is purposive sampling with criteria and data collection techniques using tests and measurements. Research conducted is a type of correlation research. According to Suharsimi Arikunto (1993), correlation research aims to find the presence or absence of that relationship. As for the design inside this research as follows:

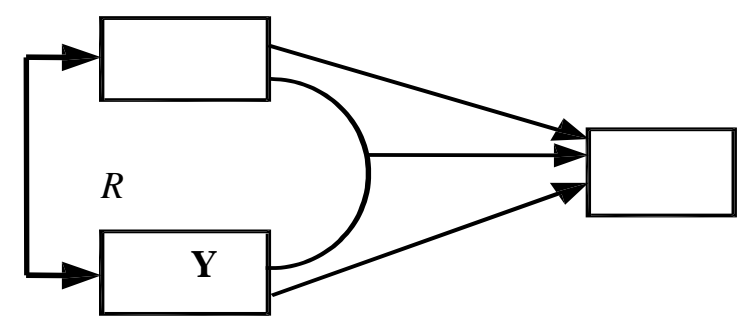

Figure 1. Researc Desain. (Source: Riduwan, 2012)
Information :
$\mathrm{X}=$ Sleeve Length
$X \quad=$ Leg Length
$\mathrm{Y}=$ Ability to swim breaststroke 50 meters

Received September $15^{\text {th }} 2020$, Revision October $8^{\text {th }} 2020$, Accepted for publication October $19^{\text {th }} 2020$. 


\section{Results and Discussion}

The research sample was PJKR 2016 students at Pattimura University Ambon, amounting to 35 male students. In this study the data in question is the data of leg length, arm length, with the ability to swim breaststroke 50 meters. by using a survey method with data collection techniques using measurements. The data in this study consisted of; (1) arm length measured using anthropometry in centimeters $(\mathrm{cm})$, (2) leg length measured in anthropometry in centimeters $(\mathrm{cm})$, and (3) 50 meter breaststroke swimming ability measured using a stopwatch in minutes. This study aims to determine whether there is a relationship between leg length and arm length with the ability to swim 50 meters breaststroke PJKR 2016 Pattimura University students. The results of the summary of research data are as follows.

Table 2. Result test

\begin{tabular}{|c|c|c|c|c|c|c|}
\hline No & $\begin{array}{c}\text { X1 (Panjang } \\
\text { Tungkai) }\end{array}$ & T_Skor & $\begin{array}{c}\text { X2 (Panjang } \\
\text { Lengan) }\end{array}$ & T_Skor & $\begin{array}{l}\mathrm{Y} \\
(50 \quad \text { Meter } \\
\text { Gaya Dada) }\end{array}$ & T_Skor \\
\hline 1 & 98 & 54 & 75 & 52 & 39.14 & $48^{\prime \prime}$ \\
\hline 2 & 90 & 38 & 70 & 41 & 40.42 & $57 "$ \\
\hline 3 & 88 & 34 & 71 & 39 & 41.56 & $36 "$ \\
\hline 4 & 95 & 48 & 74 & 50 & 40.35 & $57 "$ \\
\hline 5 & 98 & 54 & 73 & 48 & 38.16 & $40 "$ \\
\hline 6 & 102 & 62 & 79 & 62 & 44.32 & $66 "$ \\
\hline 7 & 95 & 48 & 73 & 48 & 44.09 & $48^{\prime \prime}$ \\
\hline 8 & 89 & 36 & 69 & 39 & 38.12 & $55^{\prime \prime}$ \\
\hline 9 & 97 & 52 & 76 & 55 & 45.05 & $62 "$ \\
\hline 10 & 90 & 38 & 67 & 34 & 39.48 & $50 "$ \\
\hline 11 & 104 & 66 & 81 & 66 & 45.13 & $64 "$ \\
\hline 12 & 96 & 50 & 69 & 39 & 46.32 & $39 "$ \\
\hline 13 & 92 & 42 & 73 & 48 & 41.29 & $64 "$ \\
\hline 14 & 102 & 62 & 76 & 55 & 45.29 & $51 "$ \\
\hline 15 & 90 & 38 & 75 & 57 & 38.21 & $41 "$ \\
\hline 16 & 97 & 52 & 72 & 46 & 44.36 & $57 "$ \\
\hline 17 & 100 & 58 & 81 & 59 & 44.28 & $49 "$ \\
\hline 18 & 89 & 36 & 66 & 32 & 38.57 & $36 "$ \\
\hline 19 & 93 & 44 & 73 & 36 & 44.24 & $48^{\prime \prime}$ \\
\hline 20 & 91 & 40 & 74 & 50 & 43.58 & $36 "$ \\
\hline 21 & 85 & 28 & 67 & 34 & 39.51 & $58^{\prime \prime}$ \\
\hline 22 & 101 & 60 & 79 & 57 & 47.28 & $64 "$ \\
\hline 23 & 92 & 42 & 73 & 48 & 41.78 & $55 "$ \\
\hline 24 & 97 & 52 & 75 & 52 & 43.07 & $47 "$ \\
\hline 25 & 97 & 52 & 73 & 43 & 40.28 & $41 "$ \\
\hline 26 & 101 & 60 & 78 & 59 & 46.36 & $49 "$ \\
\hline
\end{tabular}

Received September $15^{\text {th }} 2020$, Revision October $8^{\text {th }} 2020$, Accepted for publication October $19^{\text {th }} 2020$. 


\begin{tabular}{|c|c|c|c|c|c|c|}
\hline 27 & 104 & 66 & 82 & 62 & 48.32 & $58 ”$ \\
\hline 28 & 98 & 54 & 78 & 59 & 43.74 & $62 ”$ \\
\hline 29 & 96 & 50 & 74 & 50 & 42.15 & $33^{\prime \prime}$ \\
\hline 30 & 103 & 64 & 83 & 71 & 46.38 & $57 "$ \\
\hline 31 & 92 & 42 & 71 & 43 & 39.02 & $39 "$ \\
\hline 32 & 98 & 54 & 78 & 52 & 44.51 & $50 "$ \\
\hline 33 & 102 & 62 & 81 & 66 & 46.21 & $33^{\prime \prime}$ \\
\hline 34 & 94 & 46 & 74 & 39 & 43.12 & $40 "$ \\
\hline 35 & 100 & 58 & 82 & 59 & 46.59 & $62 "$ \\
\hline$\Sigma$ & & 1749 & & 1750.2 & & 1749 \\
\hline
\end{tabular}

\section{a. Leg Length}

The results of calculating the leg length data of the 2016 class of PJKR study program resulted in an average of 49.99 and a standard deviation of 10.15 The smallest value of 28 and the largest of 66. The table distribution of leg length data is as follows:

Table 3. Leg Length frekuensi distribution

\begin{tabular}{|c|c|c|c|}
\hline NO. & Interval Class & $\begin{array}{c}\text { Absolute } \\
\text { Frekuensi }\end{array}$ & $\begin{array}{c}\text { Relative } \\
\text { Frekuensi }\end{array}$ \\
\hline 1 & $28-33$ & 1 & 3 \\
\hline 2 & $34-39$ & 6 & 1 \\
\hline 3 & $40-45$ & 5 & 1 \\
\hline 4 & $46-51$ & 5 & 1 \\
\hline 5 & $52-57$ & 8 & 2 \\
\hline 6 & $58-66$ & 1 & 2 \\
\hline & & 35 & 100 \\
& & & \\
\end{tabular}

Based on the above table, it can be seen that most of the 2016 students' length of legs is in the 58-66 interval with a percentage of $29 \%$. If it is displayed in the form of a histogram, the leg length data appears in the picture as follows: 


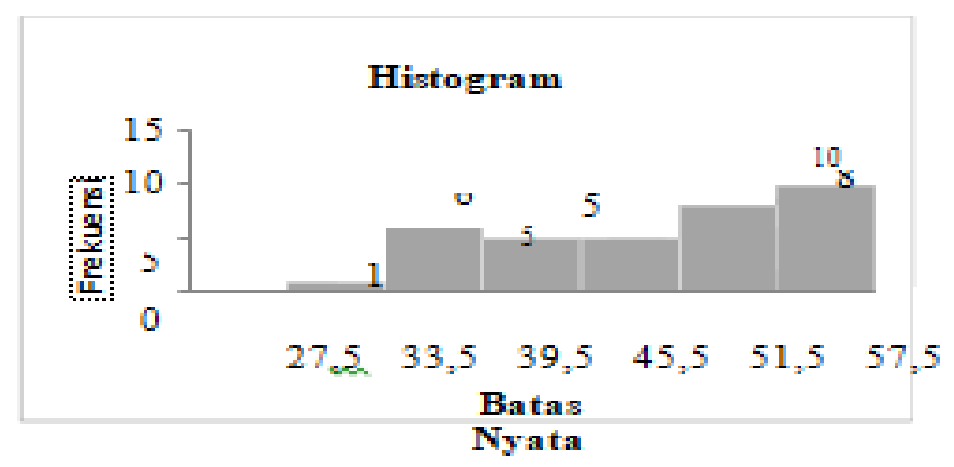

Figure 2. Leg Length Histograme

\section{b. Sleeve Length}

The results of calculating the arm length data of the 2016 class of PJKR study program resulted in an average of 50.01 and a standard deviation of 10.14 The smallest value of 31 and the largest of 69. The arm length data distribution table is as follows:

Tabel 4. Frequency Distribution of Arm Length

\begin{tabular}{|c|c|c|l|}
\hline NO. & \multicolumn{1}{|l|}{$\begin{array}{l}\text { Interval } \\
\text { Class }\end{array}$} & $\begin{array}{l}\text { Absolute } \\
\text { Frekuensi }\end{array}$ & $\begin{array}{l}\text { Relative } \\
\text { Frekuensi }\end{array}$ \\
\hline 1 & $31-36$ & 3 & 9 \\
\hline 2 & $37-42$ & 5 & 1 \\
\hline 3 & $43-48$ & 1 & 3 \\
\hline 4 & $49-54$ & 5 & 1 \\
\hline 5 & $55-60$ & 5 & 1 \\
\hline 6 & $61-69$ & 6 & 1 \\
\hline & & 3 & 10 \\
\hline
\end{tabular}

Based on the above table, it can be seen that most of the arm lengths of students in 2016 are in the $72-74$ interval with a percentage of $31 \%$. If it is displayed in the form of a histogram, the arm length data appears in the picture as follows: 


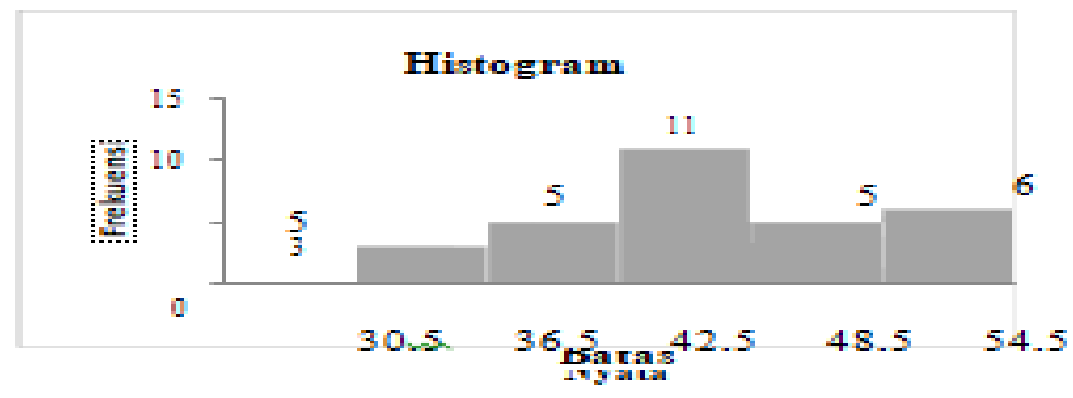

Figure 3. The Sleeve Length Histogram

\section{c. Swimming Ability of 50 Meters Chest Style}

The results of the calculation of swimming ability data of 50 meters breaststroke 2016 class year PJKR study program students produced an average of 50 and a standard deviation of 10.11. The smallest value is 34 and the biggest value is 69. The data distribution table of 50 meter breaststroke swimming ability is as follows:

Table 5. Frequency Distribution of Arm Length

\begin{tabular}{|c|c|c|c|}
\hline & Interval Class & Absolute Frekuensi & Relative Frekuensi \\
\hline & $34-39$ & 8 & 23 \\
\hline & $40-45$ & 4 & 11 \\
\hline & $46-51$ & 5 & 14 \\
\hline & $52-57$ & 9 & 26 \\
\hline & $58-63$ & 7 & 20 \\
\hline & $64-69$ & 2 & 6 \\
\hline & & 35 & 100 \\
\hline
\end{tabular}

Based on the table above, it can be seen that most of the ability to swim 50 meters breaststroke students of the class of 2016 are at intervals of 44.90-43.19 with a percentage of $31 \%$. When displayed in the form of a histogram, the 50 meter breaststroke swimming capability data can be seen in the picture as follows: 


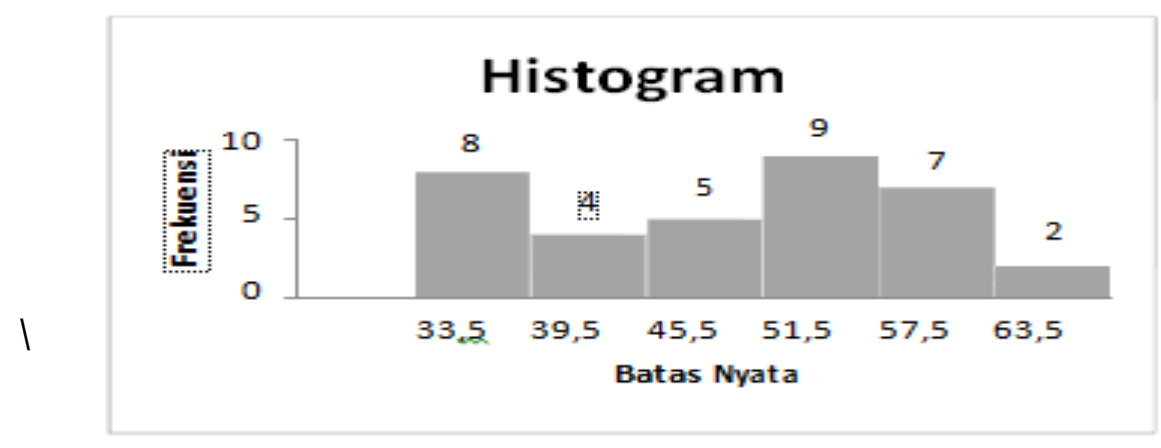

Figure 4. The 50 meter breaststroke swimming

\section{Prerequisite Test Results}

Data analysis to test hypotheses requires test requirements that must be met so that the results can be accounted for. Test requirements analysis include:

a. Normality test

The purpose of the normality test is to find out whether the data obtained from each variable analyzed actually follows the normal distribution pattern or not. In this normality test using lilifors test at a significant level $\alpha=0.05$. Normality test data can be presented in the table below:

Table 6. Normality Test

\begin{tabular}{|c|c|c|c|c|c|}
\hline No & Group & $\mathbf{N}$ & L0-count & Ltabel & \\
\hline 1 & $\mathrm{X} 1$ & 35 & 0,073 & \multirow[t]{3}{*}{0,187} & Normal \\
\hline 2 & $\mathrm{X} 2$ & 35 & 0,067 & & Normal \\
\hline 3 & $\mathrm{Y}$ & 35 & 0,088 & & Normal \\
\hline
\end{tabular}

Keterangan:

$\begin{array}{ll}\mathrm{X} 1 & : \text { Leg Length } \\ \mathrm{X} 2 & : \text { Sleeve Length } \\ \mathrm{Y} & : \text { Swimming Ability 50-meter Chest Force }\end{array}$

From the table above, it can be seen that the Lo-arithmetic of each group is smaller than Ltable (Lo-arithmetic <Ltable), this means that $\mathrm{HO}$ is accepted. Thus it can be concluded that samples from each group come from populations that are normally distributed. Then these results provide the implication that statistical analysis can be used to test the hypotheses proposed in this study, so that the first requirement for testing has been fulfilled.

\section{Hypothesis Test}

Received September $15^{\text {th }} 2020$, Revision October $8^{\text {th }} 2020$, Accepted for publication October $19^{\text {th }} 2020$. 
Analysis of research data used to test hypotheses consists of simple correlation analysis. To clarify the relationship between the independent variable and the dependent variable, multiple regression analysis is performed.

\section{a. the relationship between the length of the limbs with the ability to swim $\mathbf{5 0}$ meters breaststroke.}

The first hypothesis test reads "There is a significant relationship between arm length and swimming ability of 50 meters breaststroke 2016 PJKR students". The results of hypothesis testing using correlation regression analysis can be seen in the following table.

Table 7. Correlation Coefficient between Leg Length (X1) with Swimming Capability of 50 Meters

\begin{tabular}{|c|c|c|c|}
\hline Korel & r_hitu & $r$ & Keteranga \\
\hline asi & ng & tabel & $\mathrm{n}$ \\
\hline X1.Y & 0.728 & $5 \quad 0.32$ & Signifikan \\
\hline
\end{tabular}

Based on the results of the analysis above obtained by the correlation coefficient of leg length with swimming ability 50 meters breaststroke of 0.728 which is positive, meaning that the greater the value that affects the greater the value of the result. Test the significance of the correlation coefficient is done by consulting the price of $\mathrm{rx} 1 . \mathrm{y}=0.728$ with $\mathrm{r}(0.05)(33)=$ 0.325 . Because the correlation coefficient between $r x 1 . y=0.728>r(0.05)(32)=0.325$, it means that the correlation coefficient is significant. Thus the hypothesis that reads "There is a significant relationship between leg length and the ability to swim 50 meters breaststroke in PJKR 2016 Pattimura University students", was accepted. This means that there is a significant relationship between leg length and swimming ability of 50 meters breaststroke.

\section{b. Relationship between Arm Length With Swimming Capability of 50 Meters Chest Force}

The second hypothesis test reads "There is a significant relationship between arm length with swimming ability of 50 meters breaststroke in PJKR 2016 Ambon Pattimura University students". The results of hypothesis testing using correlation regression analysis can be seen in the following table.

Table 8. Correlation Coefficient between Arm Length (X2) with Swimming Capability of 50 Meters

\begin{tabular}{|c|c|c|c|}
\hline Correlation & r_count & r table & \\
\hline X2.Y & 0.708 & 0.325 & Signifikan \\
\hline
\end{tabular}

Based on the above analysis results obtained by the correlation coefficient of arm length with swimming ability 50 meters breaststroke of 0.708 which is positive, meaning that the greater the value that affects the greater the value of the result. Test the significance of the

Received September $15^{\text {th }} 2020$, Revision October $8^{\text {th }} 2020$, Accepted for publication October $19^{\text {th }} 2020$. 
correlation coefficient is done by consulting the price of rx1.y $=0.708$ with $\mathrm{r}(0.05)(33)=$ 0.325 . Because the correlation coefficient between $r x 1 . y=0.708>\mathrm{r}(0.05)(33)=0.325$, it means that the correlation coefficient is significant. Thus the hypothesis that reads "There is a significant relationship between arm length and the ability to swim 50 meters breaststroke in PJKR 2016 Pattimura University students", was accepted. This means that there is a significant relationship between leg length and swimming ability of 50 meters breaststroke.

\section{c. The relationship between leg length and arm length with the ability to swim $\mathbf{5 0}$ meters breaststroke}

The third hypothesis test is "There is a significant relationship between leg length and arm length with the ability to swim 50 meters breaststroke in 2016 PJKR students of Ambon Pattimura University". Using multiple regression analysis can be seen in the following table.

Table 9.Correlation Coefficient between Leg Length (X1), Arm Length (X2) with Swimming Capability of 50 Meters

\begin{tabular}{|r|r|r|l|}
\hline Correlation & r_count & r_table & \\
\hline X2.Y & 0.748 & 0.325 & Significant \\
\hline
\end{tabular}

Based on the analysis results presented in the above table, the statistical price of rx1.rx2.y $=0.764$ with $\mathrm{r}(0.05)(33)=0.325$. Because the correlation coefficient between rx1.rx2.y $=0.764>\mathrm{r}(0.05)(33)=0.325$ or this means that $\mathrm{H} 0$ is rejected. This means that there is a relationship between variable leg length and arm length with a swimming ability of 50 meters breaststroke. This means that there is a joint (simultaneous) relationship between leg length and arm length with swimming ability of 50 meters breaststroke.

This study aims to determine the significant relationship between leg length and arm length with the ability to swim 50 meters breaststroke in PJKR 2016 students at Pattimura University Ambon.

a. Relationship between Leg Length and Swimming Ability of 50 Meters of Chest Force

The analysis shows that there is a relationship between leg length and swimming ability of 50 meter breaststroke in PJKR students of 2016 Pattimura University, with a value of rx1.y $=0.728$ with $\mathrm{r}(0.05)(33)=0.325$. Because the correlation coefficient rx1.y $=0.728>\mathrm{r}(0.05)(32)=0.325$, it means that the correlation coefficient is significant. Positive value means the longer the person's limbs, the faster the swimming time is 50 meters breaststroke. The results of this analysis indicate that the longer a person's limbs, the 50 meter breaststroke swimming will be better. Long and regular leg movements have a positive effect related to the use of the lever length of a kick. By having a longer lever, it will be more beneficial when swimming. Limbs as the body's support in all activities is an important aspect in performing work optimal. Leg length is influenced by the proportion of a person's body based on hereditary or genetic aspects. To support the movement in swimming performance, long legs provide relatively better benefits compared to short limbs.

b. Relationship between Arm Length and Swimming Capacity of 50 Meters of Chest Force

Received September $15^{\text {th }} 2020$, Revision October $8^{\text {th }} 2020$, Accepted for publication October $19^{\text {th }} 2020$.

Copyright (C) 2020 Published by FKIP - Unpatti, ISSN 2721-3110 
The analysis shows that there is a relationship between arm length with swimming ability of 50 meters breaststroke in PJKR students of 2016 Pattimura University, with a value of rx1.y $=0.708$ with $\mathrm{r}(0.05)(33)=0.325$. Because the correlation coefficient rx1.y $=0.708>\mathrm{r}(0.05)(33)=0.325$, it means that the correlation coefficient is significant. Positive value means that the greater the length of a person's arms, the faster the swimming will be 50 meters breaststroke The role of arm length in swimming speed will expand traction and accelerate the rate of backward arm load, thus the longer a person's overall arm will be the farther the stroke. The further the range is assumed, if the power and speed are the same, then it will shorten the time that will be taken.

c. Relationship between Leg Length and Arm Length

The length of the legs and the length of the arms make a very efficient contribution for a swimming athlete. Therefore the results of the analysis show that there is a relationship between leg length and arm length. By producing a value for leg length of; rx1 $=0.073$ which is positive, meaning that the greater the value that affects the greater the value of the result. the significance of the correlation coefficient is done by consulting the price of $\mathrm{rx} 1=0.728$, with $\mathrm{r}(0.05)(33)=0.325$. Because the correlation coefficient, $\mathrm{rx} 1=$ $0.728>\mathrm{r}(0.05)(32)=0.325$, means the correlation coefficient is significant. While the length of the arm produces a value of; 0.708 which is positive, meaning that the greater the value obtained, the greater the value of the result. Then by consulting the price of $\mathrm{rx} 2=$ 0.708 with $\mathrm{r}(0.05)(33)=0.325$. Because the correlation coefficient $\mathrm{rx} 2=0.708>\mathrm{r}(0.05)$ $(33)=0.325$, it means that the correlation coefficient is significant. Thus the results obtained for leg length and arm length are very good, so that a person's travel time to the finish will be very maximum.

d. Relationship between Leg Length and Arm Length with Swimming Capabilities 50 Chest Force Meter

Leg length and arm length contribute very well and a short time to the ability to swim 50 meters breaststroke is evidenced by the calculation of $\mathrm{rx} 1 . \mathrm{rx} 2 . \mathrm{y}=0.764$ with $\mathrm{r}(0.05)$ $(33)=0.325$. Because the correlation coefficient between $r x 1 . r x 2 . y=0.764>r(0.05)(33)=$ 0.325 , this means that $\mathrm{H} 0$ is rejected. This means that the linear variable influence leg length and arm length. When a person has long limbs, long and regular leg movements have a positive impact related to the use of the length of the lever of a kick. By having a longer lever, it will be more beneficial when swimming. Even if someone has long arms, swimming will expand the paddle area and will accelerate the rate of forward hand stroke, the longer a person's overall arm will be, the longer it will reach. So that the length of the legs and the length of the arms are very positive influence on the travel time for swimming 50 meters breaststroke.

\section{Conclusion}

Based on the results of data analysis, description, testing of research results, and discussion, it can be concluded that:

a. There is a relationship between the length of the leg and the ability to swim 50 meters in breaststroke of 2016 Penjaskesrek University of Ambon Pattimura University students by $\mathrm{rx} 1 . \mathrm{y}=0.728$ more than $\mathrm{r} \_$tabel 0.325 . 
b. There is a relationship between the length of the arm with the ability to swim 50 meters breaststroke 2016 Penjaskesrek Universitas Pattimura Ambon student for rx2.y $=0.708$ more than r_tabel 0.325 .

c. There is a relationship between leg length and arm length of the Penjaskesrek students Pattimura University Ambon amounted to rx $1=0.728$ more than $r$ tabel 0.325 . and rx2 $=0.708$ more than $r_{-}$tabel 0.325 . There is a relationship between leg length and arm length with swimming ability 50 meters breastfeeding 2016 Penjaskesrek University Ambon Pattimura University students amounted to rx1.y and rx2.y $=0.764$ more than r_tabel 0.325 .

\section{References}

Anonim. (2011). Modul Praktinum Mata Kulia Olaraga Air (Renang). Bandung; Universitas Padjajaran.

Astrand P.O. and Rodahl. K. (1977). Texbook of Work Physiology-Physiological Bases of Exercise, 2nd edt. Mc Graw-Hill Book Company, USA. Aip Sarifudin. (1996). Evaluasi Olahraga. Jakarta; Rora karya.

Badruzaman. (2007). Modul Teori I. Bandung; Universitas Pendidikan Indonesia.

Baechle T.R \& Groves B.R. (1997). Weight Training: Steps To Success. Ahli Bahasa Latihan Beban Oleh: Razi Siregar. Jakarta; PT RajaGrafindo Persada.

Barrow H. M \& Groves R. A. (1973). Pratice Approacht to Measurement in physical Education. New York; Lea and Febiger.

Bart de Reyter. (1985). Trilomba Renang, Bersepeda, Lari. PT Rosda Jaya Putra. Ilmu Keolahragaan FIP UM. Universitas Malang.

Bompa Tuodor. O. (1994). Power Training Of Sport: Plyometrics For Maximum Power Development. Dubugue, Iowa; Kendal/hunt, publishing company

Kendal/hunt, Pub Camp.

(1999). Periodization Theory and methodology of Traing. Dubugue, Iowa; Kendal/Hunt Publising Company.

Boosey D. (1980). The Jump: Conditioning And Technical Training Victoria. Australai; Beatrice Publishing Pty, Ltd

Colwin, Cacil M. (1977). An Introdution to Swimming Coaching. Ontario; Allenbio Graphics Ltd.

Depdiknas. (2002). Pedoman dan Modul Kepelatihan Kesehatan Olahraga Bagi Pelatih Olahragawan Pelejar. Jakarta; Depdiknas.

Dewayani C.T. (2008). Belajar Renang. Semarang; Aneka Ilmu.

Received September $15^{\text {th }} 2020$, Revision October $8^{\text {th }} 2020$, Accepted for publication October $19^{\text {th }} 2020$.

Copyright (C) 2020 Published by FKIP - Unpatti, ISSN 2721-3110 
Dwikusworo Eri Pratiknyo. (2000). Petunjuk Praktis Tes dan Pengukuran Olahraga. Semarang; FIK Universitas Negeri Semarang.

Ferduchi Frederik. M. (1980). Measurement Concepts in Physical Education. London; Moosby

Company.

Received September $15^{\text {th }} 2020$, Revision October $8^{\text {th }} 2020$, Accepted for publication October $19^{\text {th }} 2020$. 
Edu Sciences J. Vol. 1. No. 3. November 2020, 208-220

Received September $15^{\text {th }} 2020$, Revision October $8^{\text {th }} 2020$, Accepted for publication October $19^{\text {th }} 2020$.

Copyright (C) 2020 Published by FKIP - Unpatti, ISSN 2721-3110 
Received September $15^{\text {th }} 2020$, Revision October $8^{\text {th }} 2020$, Accepted for publication October $19^{\text {th }} 2020$ Copyright () 2020 Published by FKIP - Unpatti, ISSN 2721-3110 
Received September $15^{\text {th }} 2020$, Revision October $8^{\text {th }} 2020$, Accepted for publication October $19^{\text {th }} 2020$.

Copyright (C) 2020 Published by FKIP - Unpatti, ISSN 2721-3110 